\title{
Kinetic studies on acid- and base-catalyzed aquation of bis-alaninatochromium(III) and on oxidation of tris- and bis-Aa-chromium(III) complexes (Aa = Gly, Ala, Asn) by $\mathrm{H}_{2} \mathrm{O}_{2}$
}

\author{
Emilia Kiersikowska • Hasan Marai • \\ Magdalena Mątewska • Grzegorz Wrzeszcz • \\ Ewa Kita
}

Received: 30 January 2014/ Accepted: 14 February 2014/Published online: 1 March 2014

(C) The Author(s) 2014. This article is published with open access at Springerlink.com

\begin{abstract}
Two aqua derivatives of $\left[\mathrm{Cr}(\mathrm{Ala})_{3}\right]$ were characterized in solution. Acid-catalyzed aquation of cis$\left[\mathrm{Cr}(\mathrm{Ala})_{2}\left(\mathrm{H}_{2} \mathrm{O}\right)_{2}\right]^{+}$leads to inert $\left[\mathrm{Cr}(\mathrm{Ala})\left(\mathrm{H}_{2} \mathrm{O}\right)_{4}\right]^{2+}$, whereas base hydrolysis of cis- $\left.\mathrm{Cr}(\mathrm{Ala})_{2}(\mathrm{OH})_{2}\right]^{-}$causes dissociation of both the Ala ligands and formation of chromates(III). Kinetics of these processes have been studied spectrophotometrically in both $0.1-1.0 \mathrm{M} \mathrm{HClO}_{4}$ and $0.2-0.9 \mathrm{M} \mathrm{NaOH}$ under firstorder conditions. A linear dependence of the $k_{\mathrm{obs}, \mathrm{H}}$ on $\left[\mathrm{H}^{+}\right]$ and a small dependence of the $\left(k_{\mathrm{obs}}\right)_{\mathrm{OH}}$ on $\left[\mathrm{OH}^{-}\right]$were established. In the proposed mechanism, the rate determining step is $\mathrm{Cr}-\mathrm{N}$ bond breaking in the reactive form of the substrate, i.e., in the protonated aqua- or dihydroxo complex. The effect of $\mathrm{pH}$ on the complex reactivity is discussed. The kinetic results are compared with those determined previously for analogous glycine and asparagine complexes. Additionally, oxidation of tris- and bis-Aa-chromium(III) complexes, where $\mathrm{Aa}=\mathrm{Gly}$, Ala or Asn, by hydrogen peroxide in alkaline medium was studied. Two reaction products were detected: thermodynamically stable $\mathrm{CrO}_{4}{ }^{2-}$ and $\left[\mathrm{Cr}\left(\mathrm{O}_{2}\right)_{4}\right]^{3-}$ that under a large excess of hydrogen peroxide is metastable. The rate-limiting stage of this process is an inner sphere twoelectron transfer within the peroxido intermediate.
\end{abstract}

\section{Introduction}

Chromium(III) complexes with biologically active ligands are potential biochromium sources. At present, many supplements containing biochromium are advertised and

E. Kiersikowska · H. Marai · M. Mątewska · G. Wrzeszcz ·

E. Kita $(\bowtie)$

Faculty of Chemistry, N. Copernicus University, 87-100 Torun, Poland

e-mail: ewakita@chem.uni.torun.pl; ewakita@chem.umk.pl recommended against obesity and type II diabetes [1-5]. However, recent reports on biochromium(III) question its vital role for mammals and conclude that there is no medical benefit in taking any chromium(III) supplements [5]. The established daily dose of chromium is now reduced to $30 \mu \mathrm{g}$ per day (instead of 50-200 $\mu \mathrm{g}$ per day [5]) and is ensured by a normal diet. As the available artificial biochromium sources contain compounds that are sparingly soluble in aqueous solution, they are practically excreted intact. Lately, a new biochromium source containing chromium-histidine complexes of higher bioavailability was advertised [6]. For this reason, we decided to consider other chromium(III)-amino acid complexes as potential biochromium sources. One group of such complexes is constituted by $f a c-\left[\mathrm{Cr}(\mathrm{Aa})_{3}\right]$ complexes and their aqua derivatives, where $\mathrm{Aa}=\mathrm{Gly}$, Ala or Asn (Scheme 1).

In our previous papers $[7,8]$, studies of the acid- and basecatalyzed aquation of chromium-glycinato and chromiumasparaginato complexes were presented. The aim of the present work was to synthesize analogous chromium(III) complexes with alanine in order to establish structure-reactivity relationships and to draw some general conclusions.

In this paper, $f a c-\left[\mathrm{Cr}(\mathrm{Ala})_{3}\right]$ and its aqua derivatives were characterized, and the kinetics of their acid- and basecatalyzed aquation were studied. Mechanisms for these reactions are postulated. As chromium compounds at higher oxidation states (IV, V, VI) are known to be toxic and are classified as human carcinogens and mutagens [9-11], it is very important to check for the possibility of oxidation of the selected chromium(III)-Aa complexes by oxidants present inside living cells (reactive oxygen species). For that reason, oxidation of $\left[\mathrm{Cr}(\mathrm{Gly})_{3}\right],\left[\mathrm{Cr}(\mathrm{Gly})_{2}(\mathrm{OH})_{2}\right]^{-}$, $\left[\mathrm{Cr}(\mathrm{Ala})_{2}(\mathrm{OH})_{2}\right]^{-}$and $\left[\mathrm{Cr}(\mathrm{Asn})_{2}(\mathrm{OH})_{2}\right]^{-}$by $\mathrm{H}_{2} \mathrm{O}_{2}$ in alkaline medium was examined and a mechanism for these processes was postulated. 
Scheme 1 Coordination mode of Gly, Ala and Asn in the fac$\left[\mathrm{Cr}(\mathrm{Aa})_{3}\right]$-type complexes

\section{Experimental}

Alanine, glycine, asparagine (Aldrich), $\mathrm{NaClO}_{4} \cdot \mathrm{H}_{2} \mathrm{O}$ (Merck) and other chemicals were used without further purification. Sephadex DEAE A-25 $\left(\mathrm{ClO}_{4}{ }^{-}\right)$and Sephadex C-25 $\left(\mathrm{H}^{+}\right)$were used for chromatographic separations. Chromium(III) complexes with glycine and asparagine of the formulae $\left[\mathrm{Cr}(\mathrm{Aa})_{3}\right]$ and $\left[\mathrm{Cr}(\mathrm{Aa})_{2}\left(\mathrm{H}_{2} \mathrm{O}\right)_{2}\right]^{+}$were prepared as described in the literature $[7,8]$.

Chromium was determined spectrophotometrically as $\mathrm{CrO}_{4}{ }^{2-}$ at $372 \mathrm{~nm}\left(\varepsilon_{372}=4,830 \mathrm{M}^{-1} \mathrm{~cm}^{-1}\right)$ after decomposition of the complexes in $0.1 \mathrm{M} \mathrm{NaOH}$ solution followed by oxidation of the chromium(III) species with $\mathrm{H}_{2} \mathrm{O}_{2}$. Alanine was determined spectrophotometrically by the ninhydrin method [12]; $\quad \varepsilon(560 \mathrm{~nm})=7,600 \mathrm{M}^{-1} \mathrm{~cm}^{-1}$. Electronic spectra were recorded using a Hewlett-Packard HP 8453 spectrophotometer equipped with a HP89090A Peltier temperature controller or Julabo F25 external thermostat.

\section{Synthesis of $\left[\mathrm{Cr}(\mathrm{Ala})_{3}\right]$}

A solution of $\mathrm{Cr}\left(\mathrm{ClO}_{4}\right)_{3}(1 \mathrm{mmol})$ and alanine $(5 \mathrm{mmol})$ in $0.1 \mathrm{M} \mathrm{HClO}_{4}\left(15 \mathrm{~cm}^{3}\right)$ was heated at $343 \mathrm{~K}$, maintaining the $\mathrm{pH}$ at ca. $5-7$ by stepwise addition of $\mathrm{NaOH}$. The reaction mixture changed color from deep blue to red and a pink precipitate was formed within ca. $10 \mathrm{~min}$. After $30 \mathrm{~min}$, the precipitate was filtered off, rinsed several times with distilled water (in order to remove unreacted alanine) and dried in the air. The composition of the product was established based on the determined 1:3 $\mathrm{Cr}$ to Ala molar ratio and its electronic absorption spectrum. Results of elemental analyses for carbon, nitrogen and hydrogen as well as the chromium content (determined from a separate sample) were consistent with $\left[\mathrm{Cr}(\mathrm{Ala})_{3}\right]$ formula (M.W. = $316 \mathrm{~g} \mathrm{~mol}^{-1}$ ): calc: $34.2 \mathrm{C}, 13.3 \mathrm{~N}, 5.74 \mathrm{H}, 16.4 \% \mathrm{Cr}$, found: $33.9 \mathrm{C}, 13.2 \mathrm{~N}, 5.79 \mathrm{H}, 16.3 \% \mathrm{Cr}$.

Products of acid-catalyzed aquation of $\left[\mathrm{Cr}(\mathrm{Ala})_{3}\right]$

A suspension of $\left[\mathrm{Cr}(\mathrm{Ala})_{3}\right](0.13 \mathrm{~g})$ in $0.4 \mathrm{M} \mathrm{HClO}_{4}$ $\left(100 \mathrm{~cm}^{3}\right)$ was kept at $323 \mathrm{~K}$ for ca. $30 \mathrm{~min}$. Then, the reaction mixture was cooled in an ice bath, neutralized with cold $3 \mathrm{M} \mathrm{KOH}$ and kept in the refrigerator for ca. $30 \mathrm{~min}$. The resulting deposit of $\mathrm{KClO}_{4}$ was filtered off and the collected pinkish-red solution was introduced onto a column of cationic exchanger $\left(\mathrm{Sp} \mathrm{C}-25, \mathrm{H}^{+}\right.$). Two distinct
Table 1 Spectroscopic characteristics of chromium(III) complexes with Gly, Ala and Asn

\begin{tabular}{llll}
\hline Complex & $\begin{array}{l}\lambda_{\max }, \mathrm{nm}^{-1} \\
\left(\varepsilon_{\max }, \mathrm{M}^{-1} \mathrm{~cm}^{-1}\right)\end{array}$ & Reference \\
\hline$\left[\mathrm{Cr}(\mathrm{Gly})_{3}\right]^{0}$ & $386(76)$ & $510(99)$ & {$[7]$} \\
{$\left[\mathrm{Cr}(\mathrm{Gly})_{2}\left(\mathrm{H}_{2} \mathrm{O}\right)_{2}\right]^{+}$} & $392(60)$ & $526(73)$ & \\
{$\left[\mathrm{Cr}(\mathrm{Gly})\left(\mathrm{H}_{2} \mathrm{O}\right)_{4}\right]^{2+}$} & $403(35)$ & $535(45)$ & \\
{$\left[\mathrm{Cr}(\mathrm{Ala})_{3}\right]^{0}$} & $380(-)$ & $508(-)^{\mathrm{a}}$ & This work \\
{$\left[\mathrm{Cr}(\mathrm{Ala})_{2}\left(\mathrm{H}_{2} \mathrm{O}\right)_{2}\right]^{+}$} & $391(60)$ & $521(80)$ & \\
{$\left[\mathrm{Cr}(\mathrm{Ala})\left(\mathrm{H}_{2} \mathrm{O}\right)_{4}\right]^{2+}$} & $404(41)$ & $531(55)$ & \\
{$\left[\mathrm{Cr}(\mathrm{Asn})_{3}\right]^{0}$} & $382(85)$ & $510(90)$ & {$[8]$} \\
{$\left[\mathrm{Cr}(\mathrm{Asn})_{2}\left(\mathrm{H}_{2} \mathrm{O}\right)_{2}\right]^{+}$} & $396(51)$ & $526(68)$ & \\
{$\left[\mathrm{Cr}(\mathrm{Asn})\left(\mathrm{H}_{2} \mathrm{O}\right)_{4}\right]^{2+}$} & $406(32)$ & $538(55)$ & \\
\hline
\end{tabular}

a spectrum in Nujol mull

bands were eluted; the first with $0.1 \mathrm{M} \mathrm{NaClO}_{4}+0.01 \mathrm{M}$ $\mathrm{HClO}_{4}$ and the second with $0.25 \mathrm{M} \mathrm{NaClO}_{4}+0.01 \mathrm{M}$ $\mathrm{HClO}_{4}$. They were identified as $\left[\mathrm{Cr}(\mathrm{Ala})_{2}\left(\mathrm{H}_{2} \mathrm{O}\right)_{2}\right]^{+}$and $\left[\mathrm{Cr}(\mathrm{Ala})\left(\mathrm{H}_{2} \mathrm{O}\right)_{4}\right]^{2+}$, respectively. As the spectrum of the first fraction changed slowly over time (even at $\mathrm{pH}$ 6-7), all kinetic studies were performed only on the freshly separated complex.

Spectroscopic characteristics for chromium(III)-Ala complexes and their analogs with glycine and asparagine are given in Table 1.

Products of $\mathrm{Fe}(\mathrm{III})$-induced aquation of $\left[\mathrm{Cr}(\mathrm{ox})(\mathrm{Ala})\left(\mathrm{H}_{2} \mathrm{O}\right)_{2}\right]^{0}$

The $\left[\mathrm{Cr}(\mathrm{ox})(\mathrm{Ala})\left(\mathrm{H}_{2} \mathrm{O}\right)_{2}\right]^{0}$ complex was prepared from $\mathrm{cis}$ $\left[\mathrm{Cr}(\mathrm{ox})_{2}\left(\mathrm{H}_{2} \mathrm{O}\right)_{2}\right]^{-}$and alanine according to the description given previously [13]. The reaction mixture was separated chromatographically using an anionic exchanger (DEAE A-25, $\mathrm{ClO}_{4}^{-}$). The initial colored effluent collected during sorption (ca. $25 \%$ yield) was introduced on the cationic exchanger. It passed through the column, demonstrating that this fraction contains only one complex, being a molecular species, i.e., $\left[\mathrm{Cr}(\mathrm{ox})(\mathrm{Ala})\left(\mathrm{H}_{2} \mathrm{O}\right)_{2}\right]^{0}$. The $\mathrm{Fe}(\mathrm{III})$ induced aquation of this complex was followed spectrophotometrically within the visible range, at $323 \mathrm{~K}$ for $30 \mathrm{~min}$. The process was performed in a tandem cell similarly as described previously [8]. The position of the lower energy $\mathrm{d}-\mathrm{d}$ transition band in the final spectrum was the same $(531 \mathrm{~nm})$ as that characteristic for the $\left[\mathrm{Cr}(\mathrm{Ala})\left(\mathrm{H}_{2} \mathrm{O}\right)_{4}\right]^{2+}$ complex $(531 \mathrm{~nm})$, obtained from $\mathrm{H}^{+}$catalyzed aquation of $\left[\mathrm{Cr}(\mathrm{Ala})_{3}\right]^{0}$ (Table 1).

Products of base hydrolysis of $\left[\mathrm{Cr}(\mathrm{Ala})_{2}\left(\mathrm{H}_{2} \mathrm{O}\right)_{2}\right]^{+}$

A solution of $\left[\mathrm{Cr}(\mathrm{Ala})_{2}\left(\mathrm{H}_{2} \mathrm{O}\right)_{2}\right]^{+}(0.3 \mathrm{mmol})$ in $0.4 \mathrm{M}$ $\mathrm{KOH}\left(50 \mathrm{~cm}^{3}\right)$ was heated at 313 for $500 \mathrm{~s}$. The reaction was then quenched by addition of an equimolar amount of 




Fig. 1 Spectroscopic changes during aquation of $\left[\mathrm{Cr}(\mathrm{Ala})_{2}\left(\mathrm{H}_{2} \mathrm{O}\right)_{2}\right]^{+}$ in $0.4 \mathrm{HClO}_{4} ;[\mathrm{Cr}]=3 \times 10^{-3} \mathrm{M}, I=1 \mathrm{M}, T=323 \mathrm{~K}$, scans every $120 \mathrm{~s}$

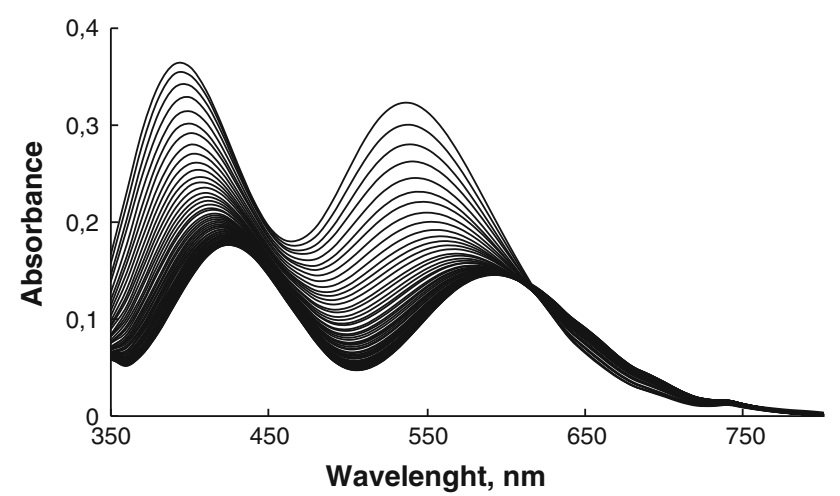

Fig. 2 Spectroscopic changes during base hydrolysis of $\left[\mathrm{Cr}(\mathrm{Ala})_{2}\right.$ $\left.(\mathrm{OH})_{2}\right]^{-}$in $0.9 \mathrm{NaOH} ;[\mathrm{Cr}]=4.5 \times 10^{-3} \mathrm{M}, I=1 \mathrm{M}, T=323 \mathrm{~K}$, scans every $10 \mathrm{~s}$

$2 \mathrm{M} \mathrm{HClO}_{4}$, keeping the mixture cold with a help of an ice bath. Next, the $\mathrm{KClO}_{4}$ precipitate was filtered off and the solution was introduced onto a column of cationic exchanger. Two pink species were eluted with $0.1 \mathrm{M} \mathrm{Na}-$ $\mathrm{ClO}_{4}+0.01 \mathrm{M} \mathrm{HClO}_{4}$ and $0.2 \mathrm{M} \mathrm{NaClO}_{4}+0.01 \mathrm{M}$ $\mathrm{HClO}_{4}$, which were identified as $\left[\mathrm{Cr}(\mathrm{Ala})_{2}\left(\mathrm{H}_{2} \mathrm{O}\right)_{2}\right]^{+}$(ca. $20 \%)$ and $\left[\mathrm{Cr}(\mathrm{Ala})\left(\mathrm{H}_{2} \mathrm{O}\right)_{4}\right]^{2+}$ (ca. $\left.25 \%\right)$, respectively. The remaining chromium was retained on the column in the form of polynuclear $\mu$-hydroxo-aquachromium(III).

Kinetic measurements

Kinetics of the acid- and base-catalyzed aquation of $\left[\mathrm{Cr}(\mathrm{Ala})_{2}\left(\mathrm{H}_{2} \mathrm{O}\right)_{2}\right]^{+}$were studied spectrophotometrically (Spectrophotometer HP 8453 equipped with HP89090 Peltier temperature controller or with Julabo F25 external thermostat) by monitoring the absorbance in the visible spectrum region. The concentrations of $\mathrm{HClO}_{4}$ and $\mathrm{NaOH}$ were varied between 0.1 and $1.0 \mathrm{M}$, and the ionic strength was $1.0 \mathrm{M}\left(\mathrm{NaClO}_{4}\right)$. Spectroscopic changes are shown in Figs. 1 and 2.
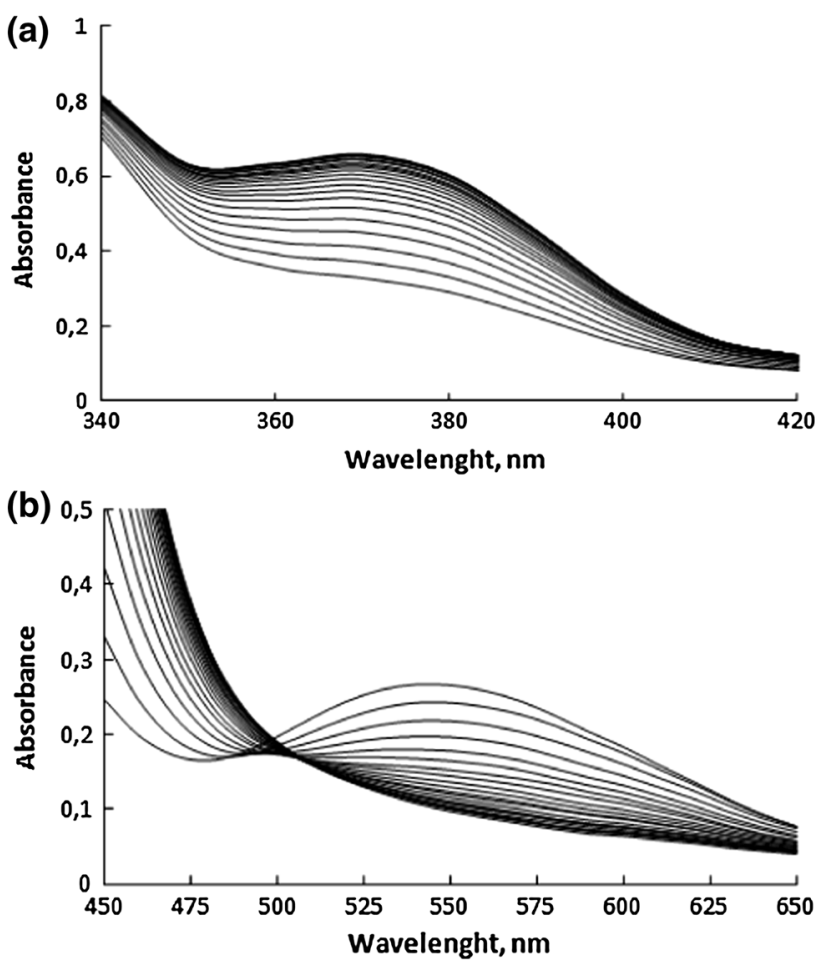

Fig. 3 Spectroscopic changes in the UV (a) and Vis (b) spectral range during oxidation of $\left[\mathrm{Cr}(\mathrm{Ala})_{2}(\mathrm{OH})_{2}\right]^{-}$by $\mathrm{H}_{2} \mathrm{O}_{2} ;[\mathrm{NaOH}]=$ $0.6 \mathrm{M},\left[\mathrm{H}_{2} \mathrm{O}_{2}\right]=0.5 \mathrm{M}, T=298 \mathrm{~K},[\mathrm{Cr}]=1.5 \times 10^{-4} \mathrm{M}(\mathbf{a})$ and $1 \times 10^{-3} \mathrm{M}(\mathbf{b})$, scans every $240 \mathrm{~s}$

The reactions were performed in a $1 \mathrm{~cm}$ tandem cell at $323 \mathrm{~K}$ (in acidic medium) and at 303-323 K (in alkaline medium). The process was initiated by mixing equal volumes $\left(0.85 \mathrm{~cm}^{3}\right)$ of the stock complex solution and the appropriate medium.

Kinetics of oxidation of $\left[\mathrm{Cr}(\mathrm{Aa})_{2}(\mathrm{OH})_{2}\right]^{-}(\mathrm{Aa}=\mathrm{Gly}$, Ala, Asn) and $\left[\mathrm{Cr}(\mathrm{Gly})_{3}\right]$ were followed by the absorbance increase within the 350-400 spectral range (Figs. 3a, 4a).

The concentration of oxidant, $\mathrm{H}_{2} \mathrm{O}_{2}$, was changed between 0.2 and $1.0 \mathrm{M}$; the concentration of $\mathrm{NaOH}$ was kept constant at $0.6 \mathrm{M}$ (taking into account neutralization of $\mathrm{NaOH}$ by $\mathrm{H}_{2} \mathrm{O}_{2}$ ) and the ionic strength was $2.0 \mathrm{M}$ $\left(\mathrm{NaClO}_{4}\right)$. The reaction was initiated by injection of $0.1 \mathrm{~cm}^{3}$ of the complex solution into $1.9 \mathrm{~cm}^{3}$ of thermostated medium solution, prepared directly before the measurement from the appropriate amounts of $\mathrm{NaOH}$ and $\mathrm{H}_{2} \mathrm{O}_{2}$ stock solutions. Additionally, some kinetic runs were performed in the Vis spectral range, using a $5 \mathrm{~cm}$ cylindric cell (Figs. 3b, 4b). In this case, the reaction was initiated by injection of $5 \mathrm{~cm}^{3}$ of the thermally equilibrated complex solution $(298 \mathrm{~K})$ into $5 \mathrm{~cm}^{3}$ of the appropriate medium solution placed in the cell, thermally equilibrated with an external thermostat.

Each kinetic run was performed for $3 t_{1 / 2}$ of the substrate conversion and was repeated at least twice. Absorbance- 

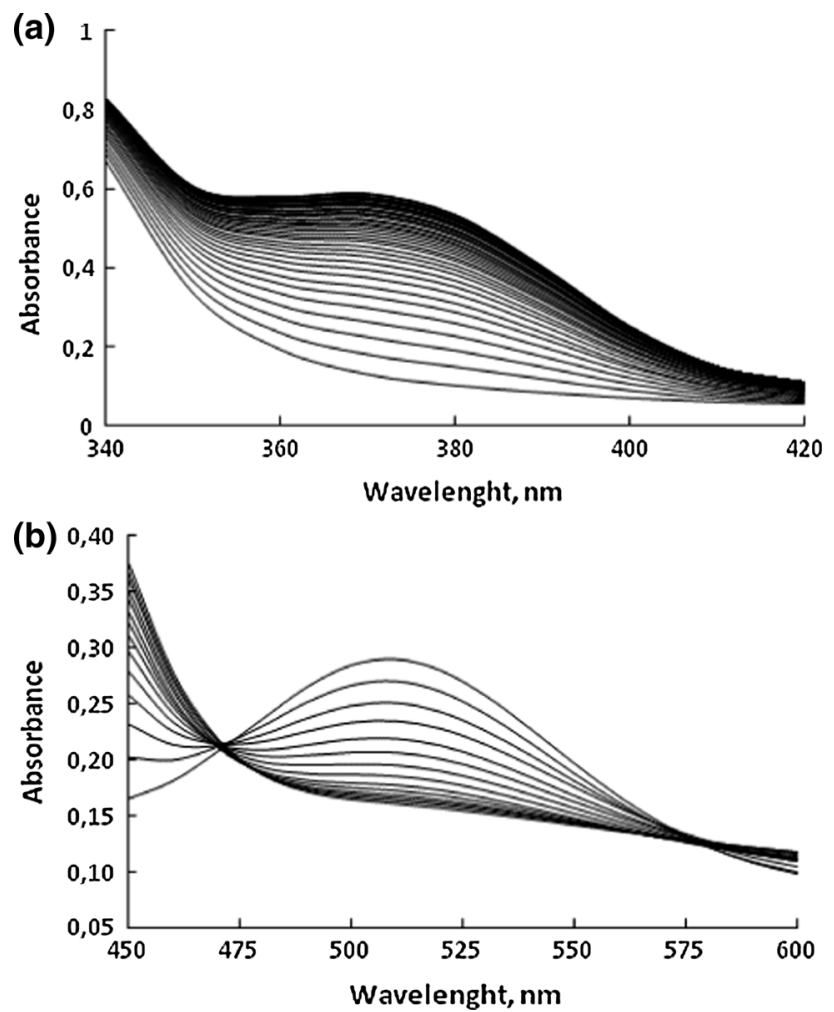

Fig. 4 Spectroscopic changes in the UV (a) and Vis (b) spectral range during oxidation of $\left[\mathrm{Cr}(\mathrm{Gly})_{3}\right]^{0}$ by $\mathrm{H}_{2} \mathrm{O}_{2} ;[\mathrm{NaOH}]=0.6 \mathrm{M}$, $\left[\mathrm{H}_{2} \mathrm{O}_{2}\right]=0.5 \mathrm{M},[\mathrm{Cr}]=1.5 \times 10^{-4} \mathrm{M}$ (a) and $1 \times 10^{-3} \mathrm{M}$ (b), $T 298 \mathrm{~K}$, scans every $80 \mathrm{~s}$

time data obeyed a pseudo-first-order dependence very well. The calculated $k_{\text {obs }}$ values were independent of the initial complex concentration. The results were also independent of the method of calculation (from absorbancetime data using the Enzfitter program or multifunctional analyses of scans recorded during the reactions studied using the SPECFIT program for a simple A $\rightarrow$ B reaction model). The relative standard errors for a single run were ca. 0.5 and those of the mean $k_{\text {obs }}$ were $1-2 \%$.

\section{EPR measurements}

EPR spectra of reaction mixtures, obtained from $\mathrm{Aa}-$ chromium(III) complexes and hydrogen peroxide, were recorded with a Radiopan EPR SE/× $2541 \mathrm{M}$ spectrometer in $\mathrm{X}$ band (ca. $9.33 \mathrm{GHz}$ ) with $100 \mathrm{kHz}$ modulation. The microwave frequency was monitored with a frequency meter. The magnetic field was measured with an automatic NMR-type magnetometer. EPR spectra were recorded at room temperature, and measurements were carried out from ca. $180 \mathrm{~s}$ after the initial mixing of reagents. A flat quartz cell was used. The solution concentrations were [Cr(III)]: $1-10 \times 10^{-4} \mathrm{M},\left[\mathrm{H}_{2} \mathrm{O}_{2}\right]: 0.4-0.76 \mathrm{M},[\mathrm{NaOH}]$ : $0.6 \mathrm{M}$. The initial intensity of the EPR signal (ca. $180 \mathrm{~s}$

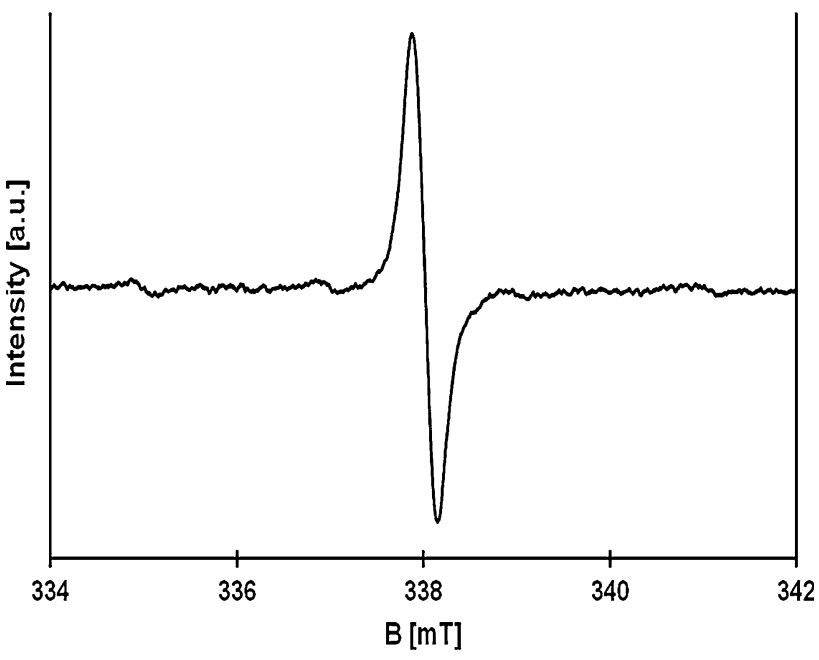

Fig. 5 EPR spectrum recorded for $2 \times 10^{-4} \mathrm{M}\left[\mathrm{Cr}(\mathrm{Ala})_{2}(\mathrm{OH})_{2}\right]^{-}$ and $0.76 \mathrm{M} \mathrm{H}_{2} \mathrm{O}_{2}$ in $0.6 \mathrm{M} \mathrm{NaOH}\left(I=2 \mathrm{M}, \mathrm{NaClO}_{4}\right)$. Other conditions: time of reaction ca. $70 \mathrm{~min}$., microwave frequency $9.33235 \mathrm{GHz}$, room temperature

from the initiation) was relatively weak, but quickly increased during the course of the reaction, reaching a maximum within a time that was dependent mainly on the system studied (Fig. 5). The lower the number of Aa ligands coordinated to chromium(III), the faster the formation of chromium(V). Finally, the EPR signal very slowly disappeared (within a few days or even weeks) due to decomposition of the stabilizing agent, namely hydrogen peroxide.

This chromium(V) species was identified as $\left[\mathrm{Cr}^{\mathrm{V}}\right.$ $\left.\left(\mathrm{O}_{2}\right)_{4}\right]^{3-}$ based on its EPR parameters, which were identical with the literature data $[14,15]$. The EPR spectrum of tetraperoxidochromate $(\mathrm{V})$ exhibits a strong isotropic signal due to chromium isotopes with $I=0(90.5 \%)$ at $g_{\text {iso }}=$ $1.9722 \pm 0.0003$ and peak-to-peak width, DBpp $\times 0.2$ $\mathrm{mT}$. A small isotropic satellite signal, split into a quartet due to hyperfine coupling by the less abundant $(9.5 \%){ }^{53} \mathrm{Cr}$ isotope $(I=3 / 2)$, is also observed with a $\left({ }^{53} \mathrm{Cr}\right)=18.59$ $10^{-4} \mathrm{~cm}^{-1}[14,15]$.

\section{Results and discussion}

Reaction between hexaaquachromium(III) and alanine yields a pink solid complex, $\left[\mathrm{Cr}(\mathrm{Ala})_{3}\right]$, of extremely low solubility. Its composition was established based on the determined 1:3 $\mathrm{Cr} / \mathrm{Ala}$ molar ratio and its electronic absorption spectrum (in Nujol mull). In acidic solution, the complex undergoes successive ligand dissociations to give diaqua and tetraaqua derivatives. This process is accompanied by a shift of ca. $10 \mathrm{~nm}$ of the $\lambda_{\max }$ of the lower energy $\mathrm{d}-\mathrm{d}$ transition band $(508,520$ and $531 \mathrm{~nm}$, 
Table 1). Comparison of the position of this band with that analogous for $\left[\mathrm{Cr}\left(\mathrm{H}_{2} \mathrm{O}\right)_{6}\right]^{3+}(574 \mathrm{~nm})$ demonstrates a remarkable red shift $(43 \mathrm{~nm})$ caused by introduction of the first Ala ligand. A similar, though slightly smaller, effect was observed in the case of analogous chromium-Asn complexes (Table 1). Based on these results, we have deduced that the previously postulated [7] spectroscopic characteristics for $\left[\mathrm{Cr}(\mathrm{Gly})_{2}\left(\mathrm{H}_{2} \mathrm{O}\right)_{2}\right]^{+}$and $\left[\mathrm{Cr}(\mathrm{Gly})\left(\mathrm{H}_{2-}\right.\right.$ $\left.\mathrm{O})_{4}\right]^{2+}$ were incorrect. The erratum to those data is given in Table 1. Anation of $\left[\mathrm{Cr}\left(\mathrm{H}_{2} \mathrm{O}\right)_{6}\right]^{3+}$ by the first amino acid ligand causes a much higher increase of the ligand field strength than introduction of the second and third ligands (Table 1). All three $f a c$-isomers are sparingly soluble in aqueous solutions; their solubility decreases in the order: $\left[\mathrm{Cr}(\mathrm{Gly})_{3}\right]>\left[\mathrm{Cr}(\mathrm{Asn})_{3}\right] \gg\left[\mathrm{Cr}(\mathrm{Ala})_{3}\right]$ and is not sufficient for performing kinetic studies for the latter complex even in the UV spectral range. Studies on acid-catalyzed aquation of fac- $\left[\mathrm{Cr}(\mathrm{Gly})_{3}\right]$ and $f a c-\left[\mathrm{Cr}(\mathrm{Asn})_{3}\right]$ revealed that dissociation of the first ligand is a fast two-stage process, initiated by the $\mathrm{Cr}-\mathrm{N}$ bond breaking $[7,8]$. Therefore, it seems reasonable to assume an analogous mechanism for aquation of $\mathrm{fac}$ $\left[\mathrm{Cr}(\mathrm{Ala})_{3}\right]$ in acidic media. For all three tris-Aa complexes, two aquation products in acidic media were identified, namely $\left[\mathrm{Cr}(\mathrm{Aa})_{2}\left(\mathrm{H}_{2} \mathrm{O}\right)_{2}\right]^{+}$and $\left[\mathrm{Cr}(\mathrm{Aa})\left(\mathrm{H}_{2} \mathrm{O}\right)_{4}\right]^{2+}$, where the diaqua species are quite labile and the tetraaqua derivatives are extremely inert.

Acid-catalyzed aquation of $\left[\mathrm{Cr}(\mathrm{Ala})_{2}\left(\mathrm{H}_{2} \mathrm{O}\right)_{2}\right]^{+}$

Among the chromium-Ala complexes, only the diaqua complex is suitable for kinetic studies in acidic media. The position of the lower energy $\mathrm{d}-\mathrm{d}$ transition band in the spectrum of $\left[\mathrm{Cr}(\mathrm{Ala})_{2}\left(\mathrm{H}_{2} \mathrm{O}\right)_{2}\right]^{+}$in $0.2 \mathrm{M} \mathrm{NaClO}_{4}$ (stored at $5{ }^{\circ} \mathrm{C}$ ) gradually shifts toward longer wavelengths; therefore, all kinetic studies were performed immediately after separation of the complex. The more distinct spectroscopic changes (Fig. 1) of the initial reaction period were assigned to $\mathrm{Cr}-\mathrm{N}$ bond breaking, whereas the smaller changes, recorded later, were attributed to the monodentate O-bonded Ala dissociation. The postulated order of $\mathrm{Cr}-\mathrm{N}$ and $\mathrm{Cr}-$ $\mathrm{O}$ cleavage is the same as that established for other chromium(III)-Aa complexes, particularly for $\left[\mathrm{Cr}(\mathrm{ox})_{2}(\mathrm{Aa})\right]^{2-}$, due to a very distinct red shift of the lower energy $d-d$ transition band during the initial reaction period (the stronger ligand field, $\mathrm{NH}_{2}$, is substituted by the weaker ligand field, $\mathrm{H}_{2} \mathrm{O}$ ) [13]. The kinetic trace did not fit a simple first-order reaction, so the collected data were analyzed for the consecutive reaction model, $\mathrm{A} \rightarrow \mathrm{B} \rightarrow \mathrm{C}$, applying SPECFIT software. Calculated values of $k_{\mathrm{obs} 1}$ and $k_{\text {obs2 }}$ are presented in Table 2 .

It is seen that the values of $k_{\text {obs1 }}$ are ca. 7 times higher than those of $k_{\mathrm{obs} 2}$. Both the rate constants are linearly dependent on $\left[\mathrm{H}^{+}\right]$:
Table 2 Values of $k_{\mathrm{obs} 1}$ and $k_{\mathrm{obs} 2}$ for the acid-catalyzed aquation of $\left[\mathrm{Cr}(\mathrm{Ala})_{2}\left(\mathrm{H}_{2} \mathrm{O}\right)_{2}\right]^{+}$at $323 \mathrm{~K}$

\begin{tabular}{lll}
\hline$\left[\mathrm{H}^{+}\right], \mathrm{M}$ & $10^{3} k_{\mathrm{obs} 1}, \mathrm{~s}^{-1}$ & $10^{4} k_{\mathrm{obs} 2}, \mathrm{~s}^{-1}$ \\
\hline 0.2 & $1.63 \pm 0.10$ & $2.73 \pm 0.20$ \\
0.4 & $2.45 \pm 0.07$ & $3.87 \pm 0.22$ \\
0.6 & $3.35 \pm 0.12$ & $4.56 \pm 0.38$ \\
0.8 & $4.37 \pm 0.16$ & $5.59 \pm 0.20$ \\
1.0 & $5.21 \pm 0.20$ & $6.84 \pm 0.84$ \\
\hline
\end{tabular}

stage I

$$
\begin{aligned}
& {\left[\mathrm{Cr}(\mathrm{Ala})_{2}\left(\mathrm{H}_{2} \mathrm{O}\right)_{2}\right]^{+} \quad \frac{+\mathrm{H}^{+}, \mathrm{K}_{\mathrm{p} 1}}{-\mathrm{H}^{+}} \quad\left[\mathrm{Cr}(\mathrm{Ala})(\mathrm{AlaH})\left(\mathrm{H}_{2} \mathrm{O}\right)_{2}\right]^{2+}} \\
& +\mathrm{H}_{2} \mathrm{O} \downarrow \mathrm{k}_{0} \quad\left(\mathrm{~S}_{1}\right) \\
& +\mathrm{H}_{2} \mathrm{O} \downarrow \mathrm{k}_{1} \\
& {\left[\mathrm{Cr}(\mathrm{Ala})(\mathrm{O}-\mathrm{Ala})\left(\mathrm{H}_{2} \mathrm{O}\right)_{3}\right]^{+} \quad \underset{\text { rapid }}{\stackrel{+\mathrm{H}^{+}}{\longrightarrow}}\left[\mathrm{Cr}(\mathrm{Ala})(\mathrm{O}-\mathrm{AlaH})\left(\mathrm{H}_{2} \mathrm{O}\right)_{3}\right]^{2+}}
\end{aligned}
$$

stage II

$$
\begin{aligned}
& {\left[\mathrm{Cr}(\text { Ala })(\mathrm{O}-\mathrm{AlaH})\left(\mathrm{H}_{2} \mathrm{O}\right)_{3}\right]^{2+} \stackrel{+\mathrm{H}^{+}, \mathrm{K}_{\mathrm{p} 2}}{-\mathrm{H}^{+}}\left[\mathrm{Cr}(\mathrm{Ala})\left(\mathrm{O}-\mathrm{AlaH}_{2}\right)\left(\mathrm{H}_{2} \mathrm{O}\right)_{3}\right]^{3+}} \\
& +\mathrm{H}_{2} \mathrm{O} \downarrow k_{0}^{\prime} \quad\left(\mathrm{P}_{1}\right) \quad+\mathrm{H}_{2} \mathrm{O} \downarrow k_{2} \quad\left(\mathrm{P}_{1} \mathrm{H}\right) \\
& {\left[\mathrm{Cr}(\text { Ala })\left(\mathrm{H}_{2} \mathrm{O}\right)_{4}\right]^{2+}+\mathrm{AlaH}_{2}^{+}}
\end{aligned}
$$

Scheme 2 Mechanism for the acid-catalyzed aquation of $\left[\mathrm{Cr}(\mathrm{Ala})_{2}\left(\mathrm{H}_{2} \mathrm{O}\right)_{2}\right]^{+}$

$k_{\mathrm{obs}, \mathrm{i}}=a_{\mathrm{i}}+b_{i}\left[\mathrm{H}^{+}\right]$

where $a_{1}=(0.67 \pm 0.06) \times 10^{-3} \mathrm{~s}^{-1}$ and $b_{1}=(4.35 \pm$ $0.08) \times 10^{-3} \mathrm{~s}^{-1} \mathrm{M}^{-1}, \quad a_{2}=(0.17 \pm 0.17) \times 10^{-4} \mathrm{~s}^{-1}$ and $b_{2}=(0.48 \pm 0.02) \times 10^{-4} \mathrm{~s}^{-1} \mathrm{M}^{-1}$

The experimental rate expression (1) is analogous to that postulated previously for acid-catalyzed aquation of $\left[\mathrm{Cr}(\mathrm{Asn})_{2}\left(\mathrm{H}_{2} \mathrm{O}\right)_{2}\right]^{+}$[8]. Therefore, the same mechanism for dissociation of the first Aa ligand from $\left[\mathrm{Cr}(\mathrm{Aa})_{2}\left(\mathrm{H}_{2} \mathrm{O}\right)_{2}\right]^{+}$ type complexes is postulated (Scheme 2).

According to Scheme 2, the first aquation stage proceeds through two parallel reaction paths; spontaneous $\left(k_{0}\right)$ and acid-catalyzed $\left(k_{1}\right)$. Thus, the determined pseudo-firstorder-rate constant is given by the expression:

$k_{\mathrm{obs} 1}=\left(k_{0}+k_{1} K_{\mathrm{p} 1}\left[\mathrm{H}^{+}\right]\right) /\left(1+K_{\mathrm{p} 1}\left[\mathrm{H}^{+}\right]\right)$

The linear dependence of $k_{\mathrm{obs} 1}$ on $\left[\mathrm{H}^{+}\right]$indicates that the limiting value for $K_{\mathrm{p} 1}$ is 0.01 . It is reasonable taking into account that protonation constant of the coordinated carboxylate group should be a few orders of magnitude lower than that of the uncoordinated carboxylate group, which is ca. 100 . Since $K_{\mathrm{p} 1}<0.01$, then $1 \gg K_{\mathrm{p} 1}\left[\mathrm{H}^{+}\right]$and expression (2) simplifies to the linear form:

$k_{\mathrm{obs} 1}=k_{0}+k_{1} K_{\mathrm{p} 1}\left[\mathrm{H}^{+}\right]$ 
An analogous rate law can be derived for the second aquation stage (Scheme 2), since the mechanisms for both stages are analogous. Thus, the meaning of the determined parameters (Eq. 1) is as follows:

$$
\begin{aligned}
a_{1}\left[\mathrm{~s}^{-1}\right]=k_{0}\left[\mathrm{~s}^{-1}\right] \text { and } b_{1}\left[\mathrm{~s}^{-1} \mathrm{M}^{-1}\right] & =k_{1}\left[\mathrm{~s}^{-1}\right] K_{\mathrm{p} 1}\left[\mathrm{M}^{-1}\right] \\
a_{2}\left[\mathrm{~s}^{-1}\right]=k_{0}\left[\mathrm{~s}^{-1}\right] \text { and } b_{1}\left[\mathrm{~s}^{-1} \mathrm{M}^{-1}\right] & =k_{2}\left[\mathrm{~s}^{-1}\right] K_{\mathrm{p} 2}\left[\mathrm{M}^{-1}\right]
\end{aligned}
$$

The kinetic parameters $a_{1}$ and $b_{1}$, characterizing the first stage, can be compared with those determined for the analogous Gly and Asn complexes at the same temperature (323 K); $0.75 \mathrm{~s}^{-1}$ and $3.63 \mathrm{M}^{-1} \mathrm{~s}^{-1}$ (Gly) and $0.51 \mathrm{~s}^{-1}$ and $0.90 \mathrm{M}^{-1} \mathrm{~s}^{-1}$ (Asn). It is seen that spontaneous aquation of all three complexes proceeds with similar rate constants. On the other hand, the pseudo rate constant for acid-catalyzed

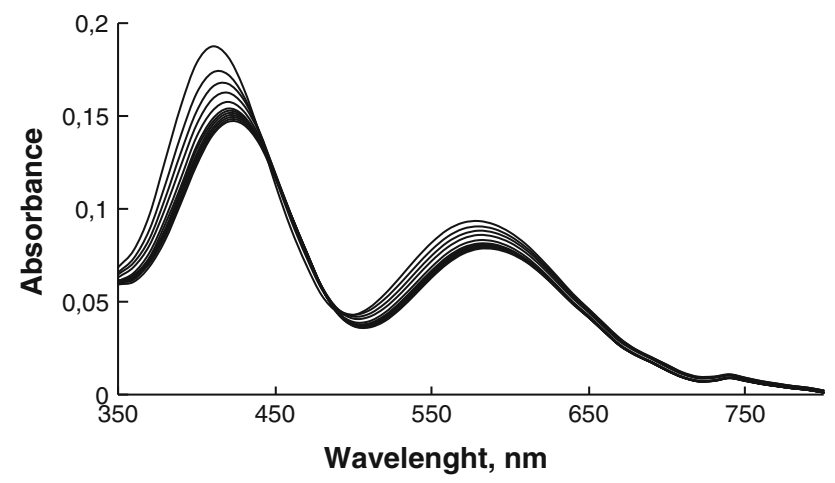

Fig. 6 Spectroscopic changes during base hydrolysis of $\left[\mathrm{Cr}(\mathrm{Ala})(\mathrm{OH})_{4}\right]^{2-}$ in $0.9 \mathrm{NaOH} ;[\mathrm{Cr}]=4 \times 10^{-3} \mathrm{M}, I=1 \mathrm{M}$, $T=298 \mathrm{~K}$, scans every $12 \mathrm{~s}$ aquation of $\left[\mathrm{Cr}(\mathrm{Asn})_{2}\left(\mathrm{H}_{2} \mathrm{O}\right)_{2}\right]^{+}$is ca. 4 times smaller than those for the Gly and Ala complexes. Such a difference may arise from protonation of the remote $\mathrm{CO}$ group, present in the side chain $\left(-\mathrm{CH}_{2}-\mathrm{CONH}_{2}\right)$, which will destabilize the chelate ring to a smaller extent than protonation of the coordinated carboxylate group, since the latter is part of the chelate ring.

Base hydrolysis of $\left[\mathrm{Cr}(\mathrm{Aa})_{2}(\mathrm{OH})_{2}\right]^{-}(\mathrm{Aa}=\mathrm{Gly}$, Ala, Asn)

In alkaline solutions, $\left[\mathrm{Cr}(\mathrm{Ala})_{2}\left(\mathrm{H}_{2} \mathrm{O}\right)_{2}\right]^{+}$exists in the dihydroxo form, which is manifested by a distinct red shift (ca. $20 \mathrm{~nm}$ ) of the lower energy d-d transition band, compared to position of this band is the diaqua complex. This complex undergoes relatively slow base hydrolysis which is accompanied by a gradual red shift of the mentioned band (up to $590 \mathrm{~nm}$ ) and an absorbance decrease (Fig. 2). Separate experiments revealed that $\left[\mathrm{Cr}(\mathrm{Ala})(\mathrm{OH})_{4}\right]^{2-}$ undergoes rapid base hydrolysis, associated with much smaller absorbance changes within the lower energy band region (Fig. 6). Therefore, it is assumed that the changes shown in Fig. 2 are characteristic for the first Ala ligand dissociation from the $\left[\mathrm{Cr}(\mathrm{Ala})_{2}(\mathrm{OH})_{2}\right]^{-}$complex.

It is obvious that Ala dissociation is a two-stage process; however, kinetic traces, recorded at different wavelengths, all showed first-order kinetics, so it was impossible to obtain separate values for each of the stages. Similar results were obtained for the analogous Gly and Asn complexes. Scans analysis (recorded between 470 and $600 \mathrm{~nm}$ ) performed with the help of SPECFIT software for the simple $\mathrm{A} \rightarrow \mathrm{B}$ reaction model, generated values of the pseudo-
Table 3 Values of $\left(k_{\text {obs }}\right)_{\mathrm{OH}}$ for base hydrolysis of $\left[\mathrm{Cr}(\mathrm{Aa})_{2}(\mathrm{OH})_{2}\right]^{-}$type complexes

\begin{tabular}{lllc}
\hline$\left[\mathrm{OH}^{-}\right], \mathrm{M}$ & $10^{3} k_{\mathrm{obs}, \mathrm{s}^{-1}}$ & \\
\cline { 2 - 4 } & {$\left[\mathrm{Cr}(\mathrm{Ala})_{2}(\mathrm{OH})_{2}\right]^{-}$} & {$\left[\mathrm{Cr}(\mathrm{Gly})_{2}(\mathrm{OH})_{2}\right]^{-\mathrm{a}}$} & {$\left[\mathrm{Cr}(\mathrm{Asn})_{2}(\mathrm{OH})_{2}\right]^{-}$} \\
\hline 0.2 & - & $1.17 \pm 0.01$ & $0.839 \pm 0.008$ \\
0.4 & $0.945 \pm 0.035$ & $1.11 \pm 0.01$ & $1.08 \pm 0.02$ \\
0.6 & $1.23 \pm 0.03$ & $1.19 \pm 0.01$ & $1.06 \pm 0.03$ \\
0.9 & $1.52 \pm 0.03$ & $1.20 \pm 0.01$ & $1.15 \pm 0.01$ \\
\hline & $313 \mathrm{~K}$ & & $2.33 \pm 0.01$ \\
\hline 0.2 & $1.78 \pm 0.06$ & $3.52 \pm 0.05$ & $2.54 \pm 0.09$ \\
0.4 & $2.53 \pm 0.05$ & $3.50 \pm 0.09$ & $2.96 \pm 0.10$ \\
0.6 & $3.01 \pm 0.04$ & $3.46 \pm 0.04$ & $3.35 \pm 0.07$ \\
0.9 & $3.47 \pm 0.03$ & $3.67 \pm 0.09$ & \\
\hline & $323 \mathrm{~K}$ & & $6.70 \pm 0.86$ \\
\hline 0.2 & $5.90 \pm 0.08$ & $9.15 \pm 0.09$ & $7.05 \pm 0.09$ \\
0.4 & $7.02 \pm 0.09$ & $9.47 \pm 0.06$ & $7.20 \pm 0.07$ \\
0.6 & $8.02 \pm 0.08$ & $9.24 \pm 0.19$ & $7.91 \pm 0.03$ \\
0.9 & $9.10 \pm 0.07$ & $9.30 \pm 0.25$ & \\
\hline
\end{tabular}




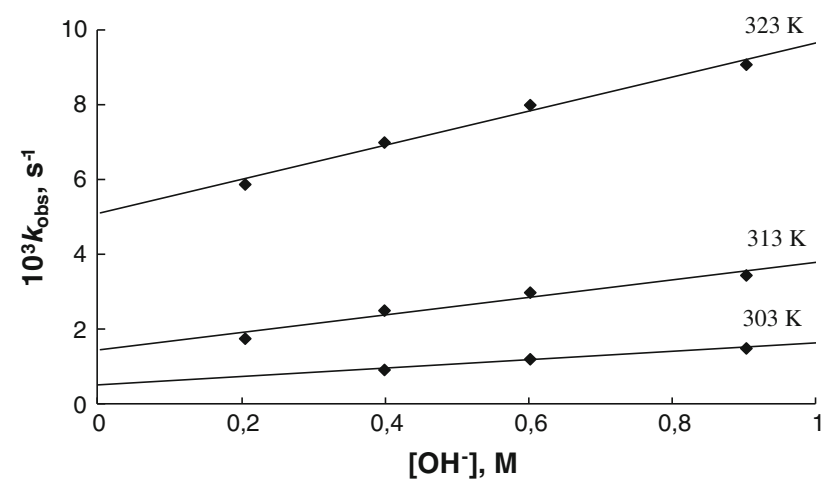

Fig. 7 Dependence of $\left(k_{\mathrm{obs}}\right)_{\mathrm{OH}}$ on $\left[\mathrm{OH}^{-}\right]$for base hydrolysis of $\left[\mathrm{Cr}(\mathrm{Ala})_{2}(\mathrm{OH})_{2}\right]^{-}$

first-order-rate constants, $\left(k_{\mathrm{obs}}\right)_{\mathrm{OH}}$, which are collected in Table 3; their dependence on $\left[\mathrm{OH}^{-}\right]$is presented in Fig. 7.

As shown by the graph, the $\left(k_{\mathrm{obs}}\right)_{\mathrm{OH}^{-}}\left[\mathrm{OH}^{-}\right]$dependence is linear (Eq. 5) and is characterized by high values of the intercepts.

$$
\left(k_{\mathrm{obs}}\right)_{\mathrm{OH}}=a_{\mathrm{OH}}+b_{\mathrm{OH}}\left[\mathrm{OH}^{-}\right]
$$

Values of the parameters $a_{\mathrm{OH}}$ and $b_{\mathrm{OH}}$ are given in Table 4.

The small dependence of $\left(k_{\mathrm{obs}}\right)_{\mathrm{OH}}$ on $\left[\mathrm{OH}^{-}\right]$(Fig. 7) can be rationalized by assuming formation of the reactive conjugate base as a result of deprotonation of the amine group or the coordinated hydroxo group (proton ambiguity). As similar small accelerating effect of $\mathrm{OH}^{-}$ions on the rate of base hydrolysis was observed also for other chromium complexes with didentate ligands without amine group (e.g., pyridinedicarboxylates) [16], we assume the latter case. Thus, the following mechanism shown in Scheme 3 can be proposed.

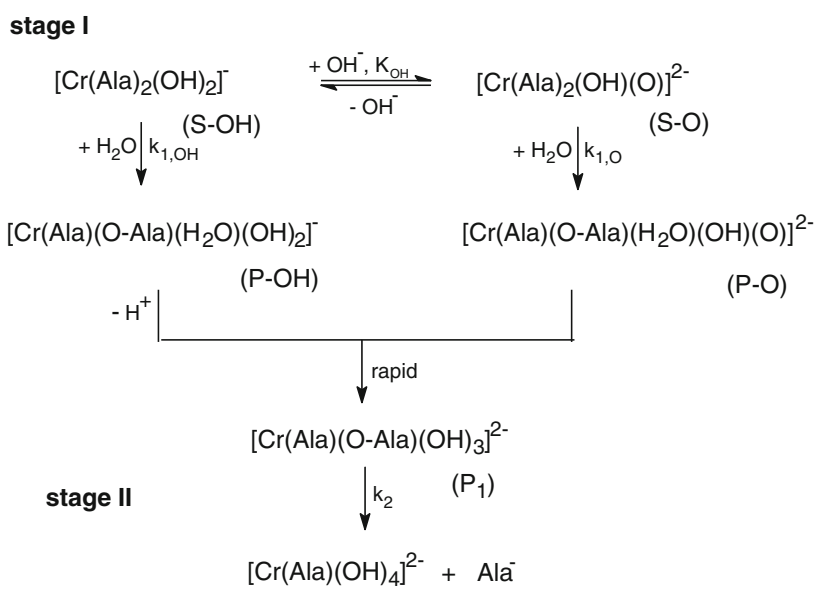

Scheme 3 Mechanism of base hydrolysis of $\left[\mathrm{Cr}(\mathrm{Ala})_{2}(\mathrm{OH})_{2}\right]^{-}$

In alkaline media, the substrate $(\mathrm{S}-\mathrm{OH})$ is in protolytic equilibrium with its conjugate base $(\mathrm{S}-\mathrm{O})$, formed as a result of deprotonation of the coordinated $\mathrm{OH}^{-}$ligand. As there is no spectroscopic evidence for the presence of such an oxo species, it is assumed that under the conditions of this study, the equilibrium characterized by $K_{\mathrm{OH}}$ is shifted left. Both of the forms undergo the same reaction, namely $\mathrm{Cr}-\mathrm{N}$ bond cleavage, leading to more reactive trihydroxo intermediate $\left(\mathrm{P}_{1}\right)$, which undergoes liberation of the monodentate O-bonded Ala ligand. The rate law derived from the proposed mechanism is of the form:

$\left(k_{\mathrm{obs}}\right)_{\mathrm{OH}}=k_{1, \mathrm{OH}}+k_{1, \mathrm{O}} K_{\mathrm{OH}}\left[\mathrm{OH}^{-}\right]$

which is analogous to the one obtained experimentally. Hence, the meaning of the parameters $a_{\mathrm{OH}}$ and $b_{\mathrm{OH}}$ is as follows:
Table 4 Values of $a_{\mathrm{OH}}$ and $b_{\mathrm{OH}}$ characterizing base hydrolysis of $\left[\mathrm{Cr}(\mathrm{Aa})_{2}(\mathrm{OH})_{2}\right]^{-}$type complexes and the activation parameters

${ }^{a}$ Reference [7]

\begin{tabular}{llll}
\hline & {$\left[\mathrm{Cr}(\mathrm{Gly})_{2}(\mathrm{OH})_{2}\right]^{-\mathrm{a}}$} & {$\left[\mathrm{Cr}(\mathrm{Ala})_{2}(\mathrm{OH})_{2}\right]^{-}$} & {$\left[\mathrm{Cr}(\mathrm{Asn})_{2}(\mathrm{OH})_{2}\right]^{-}$} \\
\hline $10^{3} a_{\mathrm{OH}}, \mathrm{s}^{-1}$ & & & \\
$303 \mathrm{~K}$ & $1.14 \pm 0.05$ & $1.13 \pm 0.12$ & $0.834 \pm 0.139$ \\
$313 \mathrm{~K}$ & $3.50 \pm 0.11$ & $2.36 \pm 0.38$ & $2.00 \pm 0.07$ \\
$323 \mathrm{~K}$ & $9.26 \pm 0.15$ & $4.55 \pm 0.37$ & $6.43 \pm 0.13$ \\
$298 \mathrm{~K}$ & 0.763 & 0.792 & 0.349 \\
$\Delta H^{\neq}, \mathrm{kJ} \mathrm{mol}^{-1}$ & $77.4 \pm 2.6$ & $53.5 \pm 0.8$ & $90.7 \pm 7.6$ \\
$\Delta S^{\neq}, \mathrm{J} \mathrm{K}^{-1} \mathrm{~mol}^{-1}$ & $-44.8 \pm 8.0$ & $-67.3 \pm 2.6$ & $-66 \pm 24$ \\
$10^{3} b_{\mathrm{OH}}, \mathrm{M}^{-1} \mathrm{~s}^{-1}$ & & & \\
$303 \mathrm{~K}$ & - & $0.52 \pm 0.08$ & $0.37 \pm 0.24$ \\
$313 \mathrm{~K}$ & - & $1.46 \pm 0.22$ & $1.51 \pm 0.12$ \\
$323 \mathrm{~K}$ & - & $5.11 \pm 0.22$ & $1.67 \pm 0.22$ \\
$298 \mathrm{~K}$ & & 0.211 & 0.522 \\
$\Delta H^{\neq}, \mathrm{kJ} \mathrm{mol}^{-1}$ & - & $99.5 \pm 6$ & $37.1 \pm 28$ \\
$\Delta S^{\neq}, \mathrm{J} \mathrm{K}^{-1} \mathrm{~mol}^{-1}$ & - & $76.0 \pm 18$ & $-126 \pm 89$ \\
\hline
\end{tabular}


$a_{\mathrm{OH}}\left[\mathrm{s}^{-1}\right]=k_{1, \mathrm{OH}}\left[\mathrm{s}^{-1}\right]$ and $b_{\mathrm{OH}}\left[\mathrm{s}^{-1} \mathrm{M}^{-1}\right]=k_{1, \mathrm{O}}\left[\mathrm{s}^{-1}\right] K_{\mathrm{OH}}\left[\mathrm{M}^{-1}\right]$

The values of $a_{\mathrm{OH}}$ and $b_{\mathrm{OH}}$, determined at different temperatures, allow the calculation of activation parameters given in Table 4. Based on the obtained values of $k_{1, \mathrm{OH}}$ and $k_{1, \mathrm{O}}(298 \mathrm{~K})$, it is seen that base hydrolysis of $\mathrm{S}-\mathrm{OH}$ in $0.1 \mathrm{M} \mathrm{NaOH}$ proceeds almost exclusively through the spontaneous path, whereas in $1 \mathrm{M} \mathrm{NaOH}$, ca. $40 \%$ of $\mathrm{P}_{1}$ (for the Ala complex) and $30 \%$ (for the Asn complexes) is generated through the $\mathrm{OH}$-catalyzed path. Comparison of the results obtained for acid- and base-catalyzed reactions at the same temperature $(323 \mathrm{~K})$ demonstrates that the hydroxo form of the substrate is much more reactive than its aqua analog at the same temperature; the value of the spontaneous rate constant $k_{0}\left(0.67 \times 10^{-3} \mathrm{~s}^{-1}\right)$ is ca. one order of magnitude lower than $k_{1, \mathrm{OH}}\left(4.55 \times 10^{-3} \mathrm{~s}^{-1}\right.$, Table 4). This is because deprotonation of the coordinated aqua ligands transforms $\left(\pi^{\mathrm{n}}\right)_{\mathrm{d}}$ into $\left(\pi^{*}\right)_{\mathrm{d}}$ orbitals, destabilizing the substrate. Values of the second-order-rate constants for acidic $\left(k_{1} K_{\mathrm{p} 1}\right)$ and alkaline $\left(k_{1, \mathrm{O}} K_{\mathrm{OH}}\right)$ media are similar (ca. $5 \times 10^{-3} \mathrm{~s}^{-1} \mathrm{M}^{-1}$ ). This result can be attributed to compensation of an expected higher value of $k_{1, \mathrm{O}}$ than $k_{1}$ by a lower value of deprotonation constant $\left(K_{\mathrm{OH}}\right)$ than protonation constant $\left(K_{\mathrm{p} 1}\right)$. It is also seen from Table 4 that the kinetic parameters for all three bis-complexes are similar.

Oxidation of $\left[\mathrm{Cr}(\mathrm{Aa})_{2}(\mathrm{OH})_{2}\right]^{-}(\mathrm{Aa}=\mathrm{Gly}$, Ala, Asn $)$ and $\left[\mathrm{Cr}(\mathrm{Gly})_{3}\right]$ by $\mathrm{H}_{2} \mathrm{O}_{2}$

Chromium(III) complexes are usually quantitatively oxidized to chromates(VI) in alkaline solutions by hydrogen peroxide, which above $\mathrm{pH} 13$ exists practically exclusively in the form of its conjugate base $\left(\mathrm{HO}_{2}{ }^{-}\right)$because $\mathrm{p} K_{\mathrm{a} 1}$ for $\mathrm{H}_{2} \mathrm{O}_{2}$ is 11.7 . The reaction can be conveniently followed spectrophotometrically at $372 \mathrm{~nm}$, the maximum of the CT transition band for $\mathrm{CrO}_{4}{ }^{2-}$. Among complexes of the $\left[\mathrm{Cr}(\mathrm{Aa})_{3}\right]$ type, only the kinetics of oxidation of the tris-Asn complex have been previously studied [8]. In this work, the kinetics of oxidation of $\left[\mathrm{Cr}(\mathrm{Gly})_{2}(\mathrm{OH})_{2}\right]^{-},\left[\mathrm{Cr}(\mathrm{Ala})_{2}(-\right.$ $\left.\mathrm{OH})_{2}\right]^{-},\left[\mathrm{Cr}(\mathrm{Asn})_{2}(\mathrm{OH})_{2}\right]^{-}$and tris- $\left[\mathrm{Cr}(\mathrm{Gly})_{3}\right]$ were examined. Unfortunately, it was not possible to perform analogous studies for the tris-Ala complex due to its extremely low solubility. The rate measurements were done at $298 \mathrm{~K}$, where the rate of $\mathrm{H}_{2} \mathrm{O}_{2}$ disproportionation can be neglected (Figs. 3, 4). It was found that all the chromium(III) was oxidized, but the yield of $\mathrm{CrO}_{4}{ }^{2-}$ was ca. $85 \%$ (for the Gly and Ala complexes) and $60 \%$ (for the Asn complexes), as determined from the absorbance value at $372 \mathrm{~nm}$ recorded after $4 t_{1 / 2}$. The lacking chromium(VI) was easily recovered by increasing the temperature. This result suggests the existence of another chromium species at intermediate oxidation stage. EPR measurements revealed that it was a chromium(V) compound, identified as the wellknown peroxido complex, $\left[\mathrm{Cr}\left(\mathrm{O}_{2}\right)_{4}\right]^{3-}[14,15]$ (see Experimental). Increase of chromium(V) concentration was observed as the EPR signal increase up to the maximal value (Fig. 5), which was constant for a long time (compared to the time scale of the redox process). This result demonstrates that under a large excess of hydrogen peroxide, at $298 \mathrm{~K}$, the $\left[\mathrm{Cr}\left(\mathrm{O}_{2}\right)_{4}\right]^{3-}$ complex is metastable. Although two chromium species are formed during oxidation, a large difference in absorbance between $\mathrm{CrO}_{4}{ }^{2-}$ and $\left[\mathrm{Cr}\left(\mathrm{O}_{2}\right)_{4}\right]^{3-}$ at $372 \mathrm{~nm}$ enables a simple correlation of the absorbance increase with the rate of chromium(III) disappearance. Direct information on the rate of $\mathrm{Cr}$ (III) disappearance was obtained from additional kinetic tests performed in the visible region, using the lower energy $\mathrm{d}-\mathrm{d}$ transition band in chromium(III) (see Experimental). It is worth mentioning that the position of $\lambda_{\max }$ of this band is unchanged during the oxidation (Figs. 3b, 4b), whereas base hydrolysis causes a large red shift of the $\lambda_{\max }$ (Fig. 2). Thus, base hydrolysis is not observed during the oxidation process.

Absorbance-time data for both the spectral regions gave a good fit for first-order-rate dependence, and the values of $\left(k_{\text {obs }}\right)_{\text {ox }}$ so obtained were very similar (Table 5 ).

The dependencies of the pseudo-first-order-rate constants $\left(k_{\mathrm{obs}}\right)_{\mathrm{ox}}$ on $\left[\mathrm{HO}_{2}{ }^{-}\right]$are shown in Figs. 8 and 9.

As shown in the figures, two types of straight lines were obtained:

$\left(k_{\mathrm{obs}}\right)_{\mathrm{ox}}=a+b\left[\mathrm{HO}_{2}^{-}\right]$

In the case of the tris-Aa complexes, the rate is strongly dependent on $\left[\mathrm{HO}_{2}{ }^{-}\right]$, as revealed by large values of the slopes and practically zero intercepts (Fig. 8). For the bisAa complexes, values of the slopes are one order of magnitude lower than those for the tris-complexes and values of the intercepts are remarkably high (Fig. 9). The determined parameters $a$ and $b$ are collected in Table 6 .

These results can be interpreted in terms of the mechanisms shown in Scheme 4.

High values of the intercepts (Fig. 9) strongly suggest an inner sphere mechanism for the redox process, as shown in mechanism a (Scheme 4). The dihydroxo complex (S-OH) is in preequilibria $\left(K_{1}\right.$ and $\left.K_{2}\right)$ with the peroxido intermediates $\left[\mathrm{I}-\mathrm{HO}_{2}\right.$ and $\left.\mathrm{I}-\left(\mathrm{HO}_{2}\right)_{2}\right]$. The value of the $K_{1}$ is so high that for formation of the $\mathrm{I}-\mathrm{HO}_{2}$ intermediate, the saturation effect is observed even at the lowest applied $\mathrm{H}_{2} \mathrm{O}_{2}$ concentration. Thus, the substrate $(\mathrm{S}-\mathrm{OH})$ is almost completely converted into the monoperoxido intermediate $\left(\mathrm{I}-\mathrm{HO}_{2}\right)$. A linear dependence of $\left(k_{\mathrm{obs}}\right)_{\mathrm{ox}}$ on $\left[\mathrm{HO}_{2}{ }^{-}\right]$is consistent with formation of the other, more reactive intermediate, $\mathrm{I}-\left(\mathrm{HO}_{2}\right)_{2}$, in trace amounts. This implies a 
Table 5 Values of $\left(k_{\mathrm{obs}}\right)_{\mathrm{ox}}$ for oxidation of the $\left[\mathrm{Cr}(\mathrm{Aa})_{2}(\mathrm{OH})_{2}\right]^{-}$and $\left[\mathrm{Cr}(\mathrm{Aa})_{3}\right]^{0}$ type complexes by $\mathrm{H}_{2} \mathrm{O}_{2}$ in $0.6 \mathrm{M} \mathrm{NaOH}$ and the yield of formed $\mathrm{CrO}_{4}{ }^{2-}$; $T=298 \mathrm{~K}$

\begin{tabular}{|c|c|c|c|c|c|c|}
\hline \multirow[t]{2}{*}[\mathrm{HO}_{2}^{-}]{, $\mathrm{M}$} & \multicolumn{2}{|c|}{$\left[\mathrm{Cr}(\mathrm{Asn})_{2}\left(\mathrm{H}_{2} \mathrm{O}\right)_{2}\right]^{+\mathrm{a}}$} & \multicolumn{2}{|c|}{$\left[\mathrm{Cr}(\mathrm{Gly})_{2}\left(\mathrm{H}_{2} \mathrm{O}\right)_{2}\right]^{+}$} & \multicolumn{2}{|c|}{$\left[\mathrm{Cr}(\mathrm{Ala})_{2}\left(\mathrm{H}_{2} \mathrm{O}\right)_{2}\right]^{+}$} \\
\hline & $10^{4} k_{\mathrm{obs}}, \mathrm{s}^{-1}$ & $\% \mathrm{Cr}(\mathrm{VI})$ & $10^{4} k_{\mathrm{obs}}, \mathrm{s}^{-1}$ & $\% \mathrm{Cr}(\mathrm{VI})$ & $10^{4} k_{\mathrm{obs}}, \mathrm{s}^{-1}$ & $\% \mathrm{Cr}(\mathrm{VI})$ \\
\hline 0.1 & $5.67 \pm 0.05$ & 63 & $4.66 \pm 0.03$ & 85 & $7.77 \pm 0.03$ & 85 \\
\hline 0.2 & $6.19 \pm 0.56$ & & $5.16 \pm 0.07$ & & $7.99 \pm 0.06$ & \\
\hline 0.4 & $6.90 \pm 0.28$ & & $5.55 \pm 0.10$ & & $8.45 \pm 0.04$ & \\
\hline 0.6 & $7.51 \pm 0.06$ & & $6.81 \pm 0.10$ & & $8.76 \pm 0.03$ & \\
\hline 0.8 & $8.98 \pm 0.35$ & & $6.51 \pm 0.10$ & & $10.2 \pm 0.20$ & \\
\hline 1.0 & $9.51 \pm 0.18$ & & $7.66 \pm 0.11$ & & $10.9 \pm 0.20$ & \\
\hline \multirow[t]{2}{*}[\mathrm{HO}_{2}^{-}]{, $\mathrm{M}$} & \multicolumn{3}{|c|}{$\left[\mathrm{Cr}(\mathrm{Asn})_{3}\right]^{0}$} & \multicolumn{3}{|c|}{$\left[\mathrm{Cr}(\mathrm{Gly})_{3}\right]^{0}$} \\
\hline & \multicolumn{2}{|c|}{$10^{3} k_{\mathrm{obs}}, \mathrm{s}^{-1}$} & $\% \operatorname{Cr}(\mathrm{VI})$ & \multicolumn{2}{|c|}{$10^{3} k_{\text {obs }}, \mathrm{s}^{-1}$} & $\% \mathrm{Cr}(\mathrm{VI})$ \\
\hline 0.2 & \multicolumn{2}{|c|}{$0.611 \pm 0.130$} & 50 & \multicolumn{2}{|c|}{$0.426 \pm 0.063$} & 90 \\
\hline 0.4 & \multicolumn{2}{|c|}{$1.03 \pm 0.07$} & & \multicolumn{2}{|c|}{$0.758 \pm 0.086$} & \\
\hline 0.6 & \multicolumn{2}{|c|}{$1.67 \pm 0.07$} & & \multicolumn{2}{|c|}{$1.20 \pm 0.17$} & \\
\hline 0.8 & \multicolumn{2}{|c|}{$2.10 \pm 0.25$} & & \multicolumn{2}{|c|}{$1.54 \pm 0.10$} & \\
\hline 1.0 & \multicolumn{2}{|c|}{$2.70 \pm 0.24$} & & \multicolumn{2}{|c|}{$1.93 \pm 0.23$} & \\
\hline
\end{tabular}



Fig. 8 Dependence of $\left(k_{\mathrm{obs}}\right)_{\mathrm{ox}}$ on $\left[\mathrm{HO}_{2}{ }^{-}\right]$for oxidation of $\left[\mathrm{Cr}(\mathrm{Asn})_{3}\right]^{0}(A)$ and $\left[\mathrm{Cr}(\mathrm{Gly})_{3}\right]^{0}(B)$ in $0.6 \mathrm{M} \mathrm{NaOH}, T=298 \mathrm{~K}$

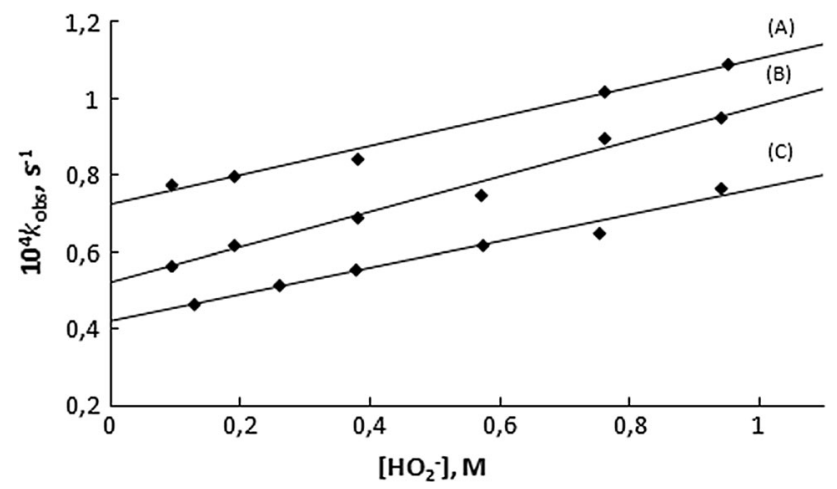

Fig. 9 Dependence of $\left(k_{\mathrm{obs}}\right)_{\mathrm{ox}}$ on $\left[\mathrm{HO}_{2}^{-}\right]$for oxidation of $\left[\mathrm{Cr}(\mathrm{Ala})_{2}(-\right.$ $\left.\mathrm{OH})_{2}\right]^{-}(A),\left[\mathrm{Cr}(\mathrm{Asn})_{2}(\mathrm{OH})_{2}\right]^{-}(B)$ and $\left[\mathrm{Cr}(\mathrm{Gly})_{2}(\mathrm{OH})_{2}\right]^{-}(C)$ in $0.6 \mathrm{M} \mathrm{NaOH}, T=298 \mathrm{~K}$

low value of $K_{2}$, which guarantees proportionality between the concentrations of $\mathrm{I}-\left(\mathrm{HO}_{2}\right)_{2}$ and $\mathrm{HO}_{2}{ }^{-}$. The rate limiting step is two-electron transfer within the intermediates via
Table 6 Values of the $a$ and $b$ parameters characterizing oxidation of the $\left[\mathrm{Cr}(\mathrm{Aa})_{2}(\mathrm{OH})_{2}\right]^{-}$and $\left[\mathrm{Cr}(\mathrm{Aa})_{3}\right]^{0}$ type complexes by $\mathrm{H}_{2} \mathrm{O}_{2}$ in $0.6 \mathrm{M} \mathrm{NaOH} ; T=298 \mathrm{~K}$

\begin{tabular}{llc}
\hline Complex & $10^{3} a, \mathrm{~s}^{-1}$ & $10^{3} b, \mathrm{M}^{-1} \mathrm{~s}^{-1}$ \\
\hline$\left[\mathrm{Cr}(\mathrm{Asn})_{3}\right]^{0 \mathrm{a}}$ & - & $2.68 \pm 0.06$ \\
{$\left[\mathrm{Cr}(\mathrm{Gly})_{3}\right]^{0}$} & - & $2.01 \pm 0.03$ \\
{$\left[\mathrm{Cr}(\mathrm{Asn})_{2}(\mathrm{OH})_{2}\right]^{-}$} & $0.522 \pm 0.017$ & $0.459 \pm 0.030$ \\
{$\left[\mathrm{Cr}(\mathrm{Gly})_{2}(\mathrm{OH})_{2}\right]^{-}$} & $0.422 \pm 0.018$ & $0.344 \pm 0.03$ \\
{$\left[\mathrm{Cr}(\mathrm{Ala})_{2}(\mathrm{OH})_{2}\right]^{-}$} & $0.728 \pm 0.018$ & $0.369 \pm 0.04$ \\
\hline
\end{tabular}

${ }^{a}$ Reference [8]

two parallel reaction paths characterized by first-order-rate constants $k_{1}$ and $k_{2}$, such that $k_{2} \gg k_{1}$. The chromium(V) complexes formed in this way undergo a fast ligand exchange and disproportionation leading to the $\mathrm{CrO}_{4}{ }^{2-}$ and $\left[\mathrm{Cr}\left(\mathrm{O}_{2}\right)_{4}\right]^{3-}$ anions. The molar ratio of $\mathrm{Cr}(\mathrm{VI}) /$ $\mathrm{Cr}(\mathrm{V})$ depends on the nature of the chelating ligand (Table 5).

Taking into account that chromates(III) are practically quantitatively oxidized to $\mathrm{CrO}_{4}{ }^{2-}$, a substantial amount of $\left[\mathrm{Cr}\left(\mathrm{O}_{2}\right)_{4}\right]^{3-}$ among the oxidation products of the Aachromium complexes indicates a rate-retarding effect on chromium(V) disproportionation caused by the chelating ligands. The highest effect is observed for the coordinated asparagine (Table 5). Thus, the lower the rate of disproportionation of chromium(V)-Aa species, the higher the proportion of the $\left[\mathrm{Cr}\left(\mathrm{O}_{2}\right)_{4}\right]^{3-}$.

The rate law consistent with mechanism a (Scheme 4) is of the form:

$$
\begin{aligned}
\mathrm{d}\left[\mathrm{CrO}_{4}^{2-}\right] / \mathrm{d} t & =-\mathrm{d}[\mathrm{Cr}(\mathrm{III})] / \mathrm{d} t \\
& =k_{1}\left[\mathrm{I}-\mathrm{HO}_{2}\right]+\mathrm{k}_{2}\left[\mathrm{I}-\left(\mathrm{HO}_{2}\right)_{2}\right]
\end{aligned}
$$


Scheme 4 Mechanisms of oxidation of $\left[\mathrm{Cr}(\mathrm{Aa})_{2}(\mathrm{OH})_{2}\right]^{-}$ (a) and $\left[\mathrm{Cr}(\mathrm{Aa})_{3}\right]$ (b) by $\mathrm{H}_{2} \mathrm{O}_{2}$ in alkaline media mechanism a

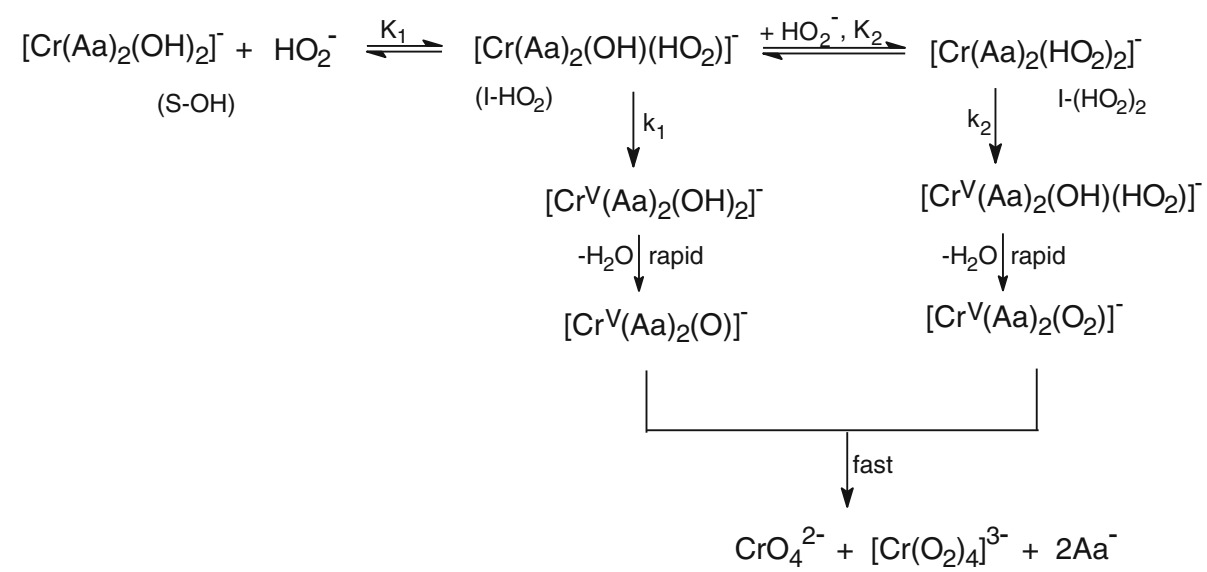

mechanism $b$

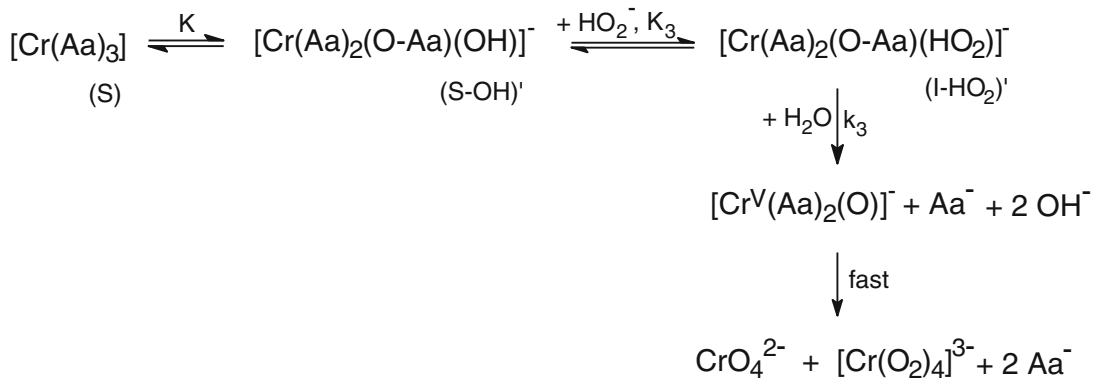

Taking into account that the $\mathrm{S}-\mathrm{OH}$ is practically exclusively converted into $\mathrm{I}-\mathrm{HO}_{2}$ and that equilibrium $\left(K_{2}\right)$ is shifted to the left, Eq. (9) can be rewritten as:

$$
\begin{aligned}
\mathrm{d}\left[\mathrm{CrO}_{4}^{2-}\right] / \mathrm{d} t & =-\mathrm{d}[\mathrm{Cr}(\mathrm{III})] / \mathrm{d} t \\
& =\left\{k_{1}+k_{2} K_{2}\left[\mathrm{HO}_{2}^{-}\right]\right\}[\mathrm{S}-\mathrm{OH}]
\end{aligned}
$$

Comparison of the experimental rate expression, $\left(k_{\mathrm{obs}}\right)_{\mathrm{ox}}=a+b\left[\mathrm{HO}_{2}{ }^{-}\right]$, with the derived rate law (10) gives the following meaning of the parameters $a$ and $b$ :

$a\left[\mathrm{~s}^{-1}\right]=k_{1}\left[\mathrm{~s}^{-1}\right]$ and $b\left[\mathrm{~s}^{-1} \mathrm{M}^{-1}\right]=k_{2}\left[\mathrm{~s}^{-1}\right] K_{2}\left[\mathrm{M}^{-1}\right]$

Thus, the intercept is the first-order-rate constant for two-electron transfer within the $\mathrm{I}-\mathrm{HO}_{2}$ intermediate, while the slope is the pseudo-second-order-rate constant, being the product of the first-order-rate constant for two-electron transfer within the $\mathrm{I}-\left(\mathrm{HO}_{2}\right)_{2}$ intermediate and the preequilibrium constant $K_{2}$. The straight line dependence of $\left(k_{\mathrm{obs}}\right)_{\mathrm{ox}}$ on $\left[\mathrm{HO}_{2}{ }^{-}\right]$up to $1 \mathrm{M} \mathrm{H}_{2} \mathrm{O}_{2}$ leads to an upper limit in the value of $K_{2}$ as $0.1 \mathrm{M}^{-1}$.

In spite of the notable differences in values of the intercept for the tris- and bis-Aa complexes, we postulate an analogous inner sphere mechanism (Scheme, mechanism b) for oxidation of both the reactant types by hydrogen peroxide. It is known that tris- $\left[\mathrm{Cr}(\mathrm{AB})_{3}\right]$ type complexes are in equilibrium with their monoaqua/hydroxo form as a result of partial dechelation of one of the coordinated didentate ligand in aqueous solution $[17,18]$. This process is characterized by a small value of the equilibrium constant, $K$ (Scheme 4$)$. The monohydroxo complex $(\mathrm{S}-\mathrm{OH})^{\prime}$ is transformed into the peroxido intermediate $\left(\mathrm{I}-\mathrm{HO}_{2}\right)^{\prime}$ in a fast, reversible step $\left(K_{3}\right)$. The linear dependence of $\left(k_{\mathrm{obs}}\right)_{\mathrm{ox}}$ on $\left[\mathrm{HO}_{2}{ }^{-}\right]$and zero value of the intercept result from a limited transformation of the hydroxo- into the peroxido-Cr(III) complex. Further reaction steps are analogous to those for the bis-Aa complexes, shown in mechanism $a$. In this case, the rate law consistent with mechanism $b$ (Scheme 4 ) is of the form:

$\mathrm{d}\left[\mathrm{CrO}_{4}^{2-}\right] / \mathrm{d} t=-\mathrm{d}[\mathrm{Cr}(\mathrm{III})] / \mathrm{d} t=k_{3} K K_{3}\left[\mathrm{HO}_{2}^{-}\right][\mathrm{S}]$

The experimental kinetic parameter $b$ is an apparent rate constant because it is the product of the equilibria and the rate constants;

$b\left[\mathrm{~s}^{-1} \mathrm{M}^{-1}\right]=k_{3}\left[\mathrm{~s}^{-1}\right] K[] K_{3}\left[\mathrm{M}^{-1}\right]$

Comparing the obtained kinetic data (Table 6), it is seen that rate of transformation of $\mathrm{Cr}(\mathrm{III})$ into $\mathrm{Cr}(\mathrm{V})$ is slightly modified by the nature of the coordinated amino acid. Reactivities of the Gly and Asn complexes are very similar and are somewhat lower than that of the Ala complex. 
Additional tests, performed (under the same conditions) for much faster oxidation of $\left[\mathrm{Cr}(\mathrm{Aa})(\mathrm{OH})_{4}\right]^{2-}$ and chromates(III) than bis-Aa- and tris-Aa complexes, revealed that the oxidation rate is substantially reduced by the presence of the second chelating ligand. The reactivity decreases with the number of coordinated $\mathrm{Aa}$ in the following order: $\mathrm{Cr}(\mathrm{Aa})_{0} \approx \mathrm{Cr}(\mathrm{Aa})_{1} \gg \mathrm{Cr}(\mathrm{Aa})_{2}>\mathrm{Cr}(\mathrm{Aa})_{3}$. Thus, the oxidation process is dramatically retarded by the presence of two Aa ligands in the inner coordination sphere of chromium(III).

\section{Conclusions}

Chromium(III) complexes with glycine, alanine and asparagine of the $\left[\mathrm{Cr}(\mathrm{Aa})_{3}\right]^{0}$ type exist as fac-isomers and are sparingly soluble in aqueous solution. They undergo two-stage acid-catalyzed aquation, where the first, faster stage is $\mathrm{Cr}-\mathrm{N}$ bond breaking. The first aquation product $\mathrm{cis}$ $\left[\mathrm{Cr}(\mathrm{Aa})_{2}\left(\mathrm{H}_{2} \mathrm{O}\right)_{2}\right]^{+}$is slowly converted into the tetraaqua derivative through parallel spontaneous and acid-catalyzed paths. In alkaline media, the appropriate dihydroxo complexes undergo base hydrolysis to give chromates(III) with rate constants that are only slightly dependent on $\left[\mathrm{OH}^{-}\right]$. The process is multistep, where the rate determining stage is $\mathrm{Cr}-\mathrm{N}$ bond breaking in the initial dihydroxo complex. Base hydrolysis of the tetrahydroxo analogs is very fast and leads to formation of chromates(III). Oxidation of these complexes leads to $\mathrm{CrO}_{4}{ }^{2-}$ and $\left[\mathrm{Cr}\left(\mathrm{O}_{2}\right)_{4}\right]^{3-}$, through a rate determining step involving the inner sphere two-electron transfer from chromium(III) to hydrogen peroxide. The nature of the Aa ligand plays a minor role in determination of the chromium(III)-Aa complex reactivity in ligand substitution and oxidation processes, whereas the number of coordinated Aa ligands is crucial.

Acknowledgments This research was supported by the NCU, Faculty of Chemistry Grants for Young Scientists No. 1506-Ch.
Open Access This article is distributed under the terms of the Creative Commons Attribution License which permits any use, distribution, and reproduction in any medium, provided the original author(s) and the source are credited.

\section{References}

1. Cefalu W, Bell-Farrow A, Stegner J et al (1999) J Trace Elem Exp Med 12:71

2. Slesinski RS, Clarke JJ, San RHC, Gudi R (2005) Mutat Res 585:86

3. Levina A, Codd R, Dillon CT, Lay PA (2003) Chromium in biology: toxicology and nutritional aspects. Prog Inorg Chem $51: 145-250$

4. Nielsen FH (2007) Summary: the clinical and nutritional importance of chromium-still debated after 50 years of research. In: Vincent JB (ed) The nutritional biochemistry of chromium(III). Elsevier, Amsterdam, pp 265-276

5. Vincent JB (2010) Dalton Trans 39:3787

6. Anderson RA, Polansky MM, Noella AB (2004) United States Patent US 6,689,383 B1, 10 Feb 2004

7. Kita E, Marai H, Muzioł T, Lenart K (2011) Transit Met Chem 36:35

8. Kiersikowska E, Marai H, Wrzeszcz G, Kita E (2013) Transit Met Chem 38:603

9. Connett P, Wetterhahn KE (1983) Struct Bond 54:93

10. Biedermann KA, Landolph JR (1990) Cancer Res 50:7835

11. Stearns DM, Wetterhahn KE (1997) NATO ASI Ser 26:55

12. Bailey JL (1962) Techniques in protein chemistry. Elsevier, Amsterdam, p 73

13. Kita E, Lisiak R (2011) Transit Met Chem 36:855

14. Dalal NS, Millar JM, Jagadeesh MS, Seehra MS (1981) J Chem Phys 74:1916

15. Zhang L, Lay PA (1998) Inorg Chem 37:1729

16. Kita E, Marai H, Jasiński M, Drewa T (2008) Transit Met Chem 33:585

17. Wilkins RG (1991) Kinetics and mechanism of reactions of transition metal complexes, 2nd edn. VCH Publishers, New York, pp 219-224

18. Jordan RB (2007) Reaction mechanisms of inorganic and organometallic systems, 3rd edn. Oxford University Press, New York, pp 104-106 